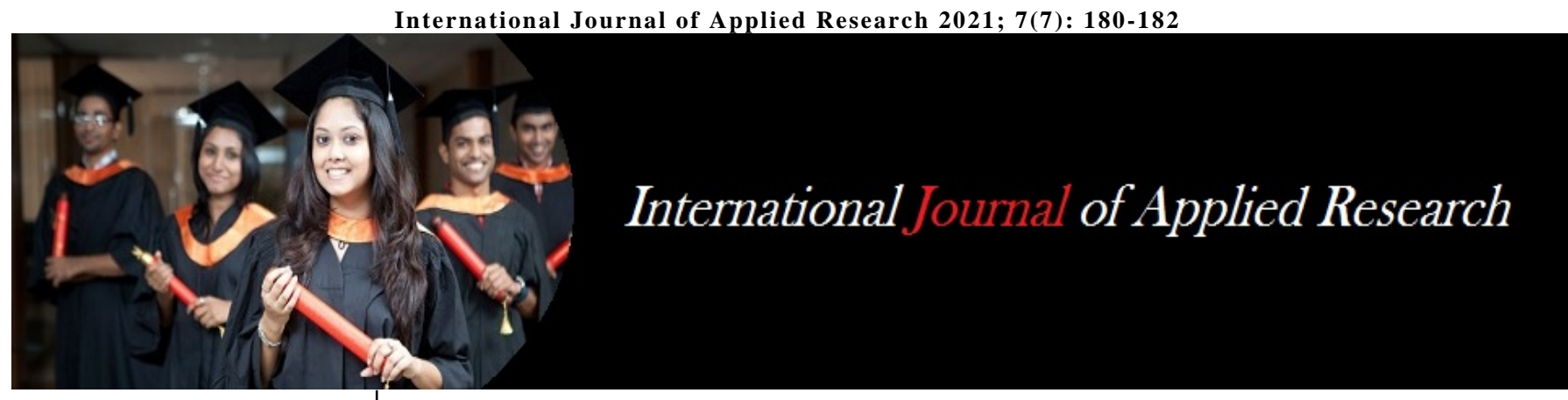

ISSN Print: $2394-7500$

ISSN Online: 2394-5869

Impact Factor: 8.4

IJAR 2021; 7(7): 180-182

www.allresearchjournal.com

Received: 21-04-2021

Accepted: 24-05-2021

Dr. Gopala Anjinappa

Principal, Government Law

College, Chamarajanagara,

Karnataka, India

\section{An etiquette of COVID-19 Law Lab in building Strong health systems}

\section{Dr. Gopala Anjinappa}

DOI: https://doi.org/10.22271/allresearch.2021.v7.i7c.8749

\section{Abstract}

This article analysis rationale behind the COVID-19 Law Lab in strengthening the health system. The coronavirus COVID-19 pandemic is the defining global health crisis and the utmost challenge that we have faced since World War Two. Since its emergence in Wuhan, China, in December 2019, the virus has eventually affected every continent except Antarctica. In an endeavor to set-up a strong legal framework \& to manage the coronavirus pandemic across the globe, the World Health Organization (WHO) launched COVID-19 Law Lab that initiates in gathering and sharing legal documents from over 190 countries across the world. The aim is to bring an accomplished law that can help in building a sound health systems in assessing and permitting safe and authentic drugs and vaccines and also in combating to create healthier and safer public spaces and workplaces. The COVID-19 Law Lab allows tracking and evaluate by what means and methods the laws and policies are being used during the Pandemic. It is an important tool for sharing good practices on laws and policies.

The article underlines the significance on the law lab that safeguard the health and welfare of individual and society and also hold on to international human rights principles. Further, the paper highlights on the Indian legislative action to control and reduce the pandemic. In addition, the paper aspires in focusing different legal frameworks for COVID-19 in India.

Keywords: COVID-19 law lab, health system, laws, policies, international human rights etc.

\section{Introduction}

The coronavirus COVID-19 is an unprecedented health crisis. This epidemic badly affected the health systems and tightened the frontline health workers. During the pandemic era, the health care plays a vital role to fight against the spread of the virus. In the light of COVID-19 a new Portal, COVID-19 Law Lab (CLL), was launched on $5^{\text {th }}$ May, 2020 to support the global emergency by gathering all recent legal enactments to battle the novel coronavirus disease pandemic. However, it is an online portal and not a cubical laboratory. The new Lab is a joint venture of the World Health Organization (WHO), United Nations Development Programme (UNDP), the Joint United Nations Programme on HIV/AIDS (UNAIDS), and the O’Neill Institute for National and Global Health Law at Georgetown University ${ }^{[1]}$.

The system endeavors in supporting the countries to achieve universal health coverage by working with policymakers, civil society groups and other stakeholders to outline laws that ensure that all people and communities have the right to access the leading, protective, therapeutic and rehabilitative health services they need. It also aims at dissemination of procedures and practices for the effective enactment of health-related laws. It is expected to be the most liberal and wide proliferate of laws and procedures related to a health emergency.

The COVID-19 Law Lab is a profile of laws that countries have implemented in return to the pandemic. It includes state of emergency declarations, quarantine measures, disease surveillance, legal measures relating to mask-wearing, social distancing, and access to medication and vaccines. It also attributes to research on distinct legal frameworks for COVID-19. This scheme will help countries to identify the best practices transfusing their immediate responses to COVID-19 pandemic.

\section{A need for consistent legal framework}

As health is universal, legal frameworks need to be united with international commitments to react to on the rise of public health risks.
Dr. Gopala Anjinappa Principal, Government Law College, Chamarajanagara, Karnataka, India 
A new COVID-19 Law Lab (CLL) emerged instantly by the World Health Organization (WHO) to facilitate a consistent legal framework with an aspiration to provide fundamental legal information and support for the global upshot to the pandemic. The CLL facilitates states to develop, establish and implement a legal framework to deal with COVID-19 by collecting and sharing legal documents from more than 190 countries.

\section{World health organization (WHO)}

The WHO Country Office for India (WCO India) has been working closely with the Government of India (GoI) to stepup preparedness and response measures for COVID-19, including surveillance and contact tracing, laboratory testing, risk communications and community engagement, hospital preparedness, infection prevention and control, and implementation of containment plan at all three levels of the health system - national, state and district. The entire field presence, including the National Public Health Surveillance Project, consisting of more than 2000 personnel has been fully re-purposed to support the government to overcome this challenge ${ }^{[2]}$.

\section{United nations development programme (UNDP)}

UNDP is the major United Nations organization combating to end the unfairness of poverty, inequality, and climate change. Drawing on its experience with other outbreaks such as Ebola, HIV, SARS, TB and malaria, as well as our long history of working with the private and public sector, UNDP will help countries to urgently and effectively respond to COVID-19 as part of its mission to eradicate poverty, reduce inequalities and build resilience to crises and shocks ${ }^{[3]}$.

UNDP India is supporting priorities in support of Government responses. These include supporting health systems; addressing social and economic impacts; and supporting multi-sectoral coordination and inclusive responses. UNDP is out-breaking its extensive programmes and partnerships in India and drawing on its global network and expertise to support the response to COVID-19. The aim is to support the Government of India and State Governments in strengthening and accelerating a whole of society approach and response, working in collaboration with UN, private sector, civil society and development partners. UNDP is also actively working with partners on mobilizing resources for the short and long term needs of the crisis, including preparing for and protecting people from the pandemic and its impacts; responding to the outbreak; and recovering from the economic and social impacts ${ }^{[4]}$.

\section{Joint united nations programme on HIV/AIDS (UNAIDS)}

The UNAIDS is an innovative joint venture of the United Nations family which brings together the efforts and resources of $11 \mathrm{UN}$ system organizations to unite the world against AIDS - UNHCR, UNICEF, WFP, UNDP, UNFPA, UNODC, UN Women, ILO, UNESCO, WHO and the World Bank ${ }^{[5]}$. UNAIDS is urging people to act with kindness, not stigma and discrimination - people affected by COVID-19 are part of the solution and need to be supported. UNAIDS recognizes, however, that in many countries, owing to weaker healthcare systems, informal settlements, overcrowded cities and public transportation and a lack of clean water and sanitation, the current approaches to selfprotection and social distancing ${ }^{[6]}$.

UNAIDS is also committed to eradicating all forms of discrimination faced by transgender communities and stands behind them to drive workplace equality forward. Recognizing that access to finance is a critical factor towards supporting vulnerable populations to survive the immediate crisis and the impact of lockdowns, UNAIDS and partners launched the Solidarity Fund for Key Populations Social Entrepreneurships and will support eight proposals for transgender-led social enterprises in its pilot phase. The selected applicants for the pilot phase of the solidarity fund have shown how civil society organizations and networks are playing a critical role in providing essential social safety nets for vulnerable communities and transgender populations during the pandemic. In Bihar, India, Reshma Prasad sees a unique opportunity for the transgender community, which has developed unique skills in dancing, singing, art and entertainment within the local culture and across the country. Through Nachbaja, Ms. Prasad bridged the current gap between transgender communities and digital media by providing a centralized online platform on which they can market their skills, allow people to directly connect with the artists themselves and provide the artists with an opportunity to receive fair pricing and wider exposure for their services. Nachbaja.com has already been registered more than 1000 artists for its platform and aims to grow the platform to reach all of India [7].

\section{O'neill institute for national and global health law and George Town University}

The O'Neill Institute, housed at Georgetown University, was established to create innovative solutions to the most pressing national and international health concerns, with the essential vision that the law has been, and will remain, a fundamental tool for solving critical health problems. The collation initiative of COVID-19 Law Lab aims at dissemination of procedures and practices for effective enactment of laws. Katie Gottschalk, executive director of the O’Neill Institute for National and Global Health Law at Georgetown University Law Center, said:

"We must learn lessons from the early stage of pandemic policies to implement the most effective laws going forward - the COVID-19 Law Lab allows us to do just that" [8].

\section{Universal health coverage (UHC) legal solutions network}

On the $74^{\text {th }}$ United Nations General Assembly, the UNDP, the UNAIDS, the Inter-Parliamentary Union (IPU), the WHO, and Georgetown University's O’Neill Institute launched a new collaboration to support Universal Health Coverage (UHC), the UHC Legal Solutions Network ${ }^{[9]}$. The COVID-19 Law Lab is a product of the UHC Legal Solutions. The initiative aims to support countries to achieve universal health coverage by working with policymakers, civil society groups and other stakeholders to craft laws ensure that all people and communities have the right to access the health services they need, of sufficient quality.

In October 2019, the Inter-Parliamentary Union (IPU) adopted a landmark resolution calling to parliaments take all legal and policy measures to achieve universal health coverage (UHC) by 2030. The resolution urges parliaments 
to put in place effective UHC legislation to ensure that the right to health and medical care is guaranteed for all in law and in practice, without discrimination ${ }^{[10]}$.

\section{COVID-19 law lab and India}

The law lab will aspire research on different legal frameworks for COVID-19. It builds off the work of the UHC Legal Solutions Network, which was established to help countries achieve universal health coverage through the implementation of the rights-based legal frameworks. as many governments have introduced emergency laws in response to COVID-19, India has also contributed 15 documents to this database that includes India Containment Plan for Large Outbreaks of COVID-19, Epidemic Diseases Act, 1897, India Disaster Management Act, 2005, invoked for COVID-19, Government of NCT Delhi COVID Regulations, Maharashtra State Regulations, India Order against Landlords COVID-19 (NCT Delhi), Telemedicine Guidelines, Amendment to Epidemic Diseases Act, Kerala Epidemic Diseases Ordinance, COVID-19 Regulations, 2020, etc.

However, there was no legal framework for regulating private labs in India. Only two mechanisms, namely accreditation and public procurement have sought to fill the regulatory void in the diagnostics industry. The lack of a regulatory framework led to confusion regarding the role of private labs in the response to the COVID-19 pandemic. As a result, the government set up an emergency regulatory framework for the COVID-19 crisis using provisions of the Epidemic Diseases Act, 1987, and the Disaster Management Act, 2005. Using these laws, it appointed the Indian Council of Medical Research (ICMR) as the apex decision-making body for India's diagnostic testing strategy through the Ministry of Health \& Family Welfare (MoHFW).

The Epidemics Act empowers the state governments to take extraordinary measures and recommend regulations to control the spread of a harmful epidemic disease. It lists a set of basic subjects for which regulations may be made such as travel restrictions, examination and quarantine of suspected cases, and inspections of any ship or vessel leaving or arriving at any port of call.

The Disaster Management Act comprises an administrative framework for disaster management. The COVID-19 pandemic has been reported as a disaster under this Act. Under this, the government has passed various directives on different aspects of the COVID-19 response using the umbrella clauses of this legislation such as section 6(2) (i) (The NDMA may lay down the policies, plans and guidelines for disaster management) and Section 10(2) (l) (The National Executive Committee may lay down guidelines or give directions to union ministries, state governments and state authorities for responding to the disaster) have been invoked to respond to the COVID-19 crisis.

\section{Conclusion}

As health is a universal issue, a well-built source of law for health is very much imperative. Towards this angle, the legal frameworks should be associated with international commitments to respond to the existing and up-coming health risks. COVID-19 Law Lab is an essential channel for sharing good practices on laws and policies. Laws and policies that are built in science, evidence and human rights can facilitate people to access health services, protect themselves from COVID-19 and live free from stigma, discrimination and violence. Tracking and evaluating how laws and policies are being used is very crucial better understand what works in pandemic situation. As now, it is a time for India to review what changes, if any, need to be introduced into its legal regimes so as to be able to act effectively and timely to address the devastating effects of the COVID-19 pandemic.

\section{References}

1. COVID-19 Law Lab, Collecting legal documents from the COVID-19 response. Available at: covidlawlab.org

2. WHO, South East Asia, India, Coronavirus Disease (COVID-19). Available at:

www.who.int/india/emergencies/coronavirus-disease(covid-19)

3. UNDP, COVID-19 pandemic Humanity needs leadership and solidarity to defeat the coronavirus. Available at:

www.undp.org/content/undp/en/home/coronavirus.html

4. Support to the National Response to contain the impact of COVID-19, UNDP, India. Available at: www.in.undp.org/content/india/en/home/covid-19pandemic-response/support-to-national-response1.html

5. United Nations, Office of the Secretary General's Envoy on Youth. Available at: www.un.org/youthenvoy/2013/08/unaids-joint-unitednations-programme-on-hivaids

6. UNAIDS, COVID-19 and HIV. Available at: www.unaids.org/en/covid1

7. Solidarity fund helping transgender people during the COVID-19 pandemic, FEATURE STORY, UNAIDS 2021. Available at:

www.unaids.org/en/resources/presscentre/featurestories /2021/march/20210330_solidarity-fund-transgenderpeople

8. COVID-19: A lab for COVID-related laws, Down to Earth, News 2020. Available at: www.downtoearth.org.in

9. O’Neill Institute for National \& Global Health Law, Georgetown Law, UHC Legal Solutions Network. Available at: oneill.law.georgetown.edu/uhc-legalsolutions-network

10. A UHC2030 Partner Insight on universal health coverage (UHC) from the Inter-Parliamentary Union (IPU), Parliamentarians: a strong role in the regulatory and legal environment for UHC, UHC 20302020. Available at: www.uhc2030.org/blog-news-events/uhc2030-news 